\title{
Cultural clusters in the post-industrial city: the Greek experience
}

\author{
A. Gospodini \\ Department of Planning \& Regional Development, \\ University of Thessaly, Volos, Greece
}

\begin{abstract}
This paper is concerned with cultural economies in the post-industrial city and examines the phenomenon of cultural and leisure clusters in Greek cities. In the first part, the paper discusses the key-role of cultural economies in the post-industrial city and presents types of cultural clusters in inner city areas. The second part focuses on Greek cities and analyses three cultural and leisure clusters in Athens, Thessaloniki and Volos. The paper documents the spontaneous formation and the 'laissez-faire' development of such clusters; it records the shift of land-uses and the transformations of urban landscape while it highlights the urban policies involved. Finally, it draws conclusions on the formation and management of cultural and leisure clusters and especially, the differences among large cities in the core of Europe and Mediterranean large cities in the developing periphery of Europe.

Keywords: cultural and leisure economies, spontaneous clusters, urban landscape transformations, post-industrial city, Greek cities.

\section{Cultural economies and cultural leisure clusters in the post-industrial city}

Throughout urban history, cities have always exhibited a capacity to act as centres of cultural activities and generate culture in the form of various arts and styles, new ideas and attitudes. However, since the 1990s, the post-industrial city is witnessing an accelerating pace of growth of cultural and leisure economic activities. In the new milieu of economic globalisation and volatility of capital and enterprises, the relocation of traditional industries in developing regions was 
accompanied by an unprecedented growth of cultural and leisure industries in mature cities. Production and consumption of culture and leisure (arts, fashion, music, food, tourism) and the industries that cater to it, along with 'creative industries' containing design (in architecture, fashion, graphics, internet, etc), have become the growth engine of the post-industrial city [1-7]. As argued by Sir Peter Hall [7], cities have passed at extraordinary speed from manufacturing to informational economy and from informational economy to a cultural economy; and 'culture is now seen as the magic substitute for all the lost factories and warehouses, and as a device that will create a new urban image, making the city more attractive to mobile capital and mobile professional workers' ([7]: 640).

A large number of studies have measured particular parameters and analysed different sectors of the cultural and leisure urban economies [5-11]. Scott [5,6] interprets the accelerating pace of growth of cultural industries as a result of both the increasing disposable consumer income and the discretionary time of the middle classes in developed countries. On the same line, Clark [12] describes an emerging 'amenity urban growth', both economic and demographic, rooted in the fact that educated and talented young professionals and high-tech staff, who can locate themselves where they choose, are mainly courted by cities that compete for them with public amenities. Thus, for Clark et al, leading urban policies are now passing from the provision of larger incentives to enterprises than the competing locations to the provision of lifestyle amenities for visitors and mainly for residents [12].

The post-modern accelerating pace of growth of cultural and leisure economic activities in cities has been accompanied by a parallel strong proclivity to clustering: Before the 1990s, cultural buildings and building complexes, even those representing big architectural statements and flagship projects like for instance, President's Mitterand 'Grands projets' in Paris, were more or less randomly distributed over the plan of the inner city - perhaps realising some small and ad hoc local concentrations. Since the 1990s, as Mommaas [13] argues, cultural clustering represents a next stage in the on-going use of culture as a growth engine in urban economy, 'a shift from a policy aimed at organising occasions for spectacular consumption to a more fine-tuned policy, also aimed at creating spaces, quarters and milieus for cultural production and creativity' ([13]: 508). A significant such case is the Museum Quarter in Vienna that consists of 20 museums and cultural institutes covering a surface of 60,000 sq.m.

Evidence to the trend of clustering of cultural and leisure economic activities is a growing number of studies on various kinds of such clusters - for instance, clusters of television and film making ([14-16]), clusters of leisure and nighttime economy $[10,11,17,18]$, clusters of fashion design $[19,20]$, clusters of ethnic restaurants and ethnic fashion [21].

In some cases clusters of cultural and leisure activities are spontaneously created due to the advantages and economic benefits produced by spatial neighbouring. These advantages and benefits may be conceived in relation to the particularities of cultural industries in terms of production relations and distribution methods, as described by Scott [5]. Labour processes in cultural 
industries involve considerable amounts of handiwork complemented by computer technologies; production is organised in dense networks of medium to small sized establishments strongly dependent on one another for specialised inputs and services; these networks form multifaceted industrial complexes that may reduce, for both employers and employees, the risks deriving from frequent recurrent job-search; cultural industries are invariably replete with external economies, many of which can only be effectively appropriated via location based agglomeration which gives rise to mutual learning and cultural synergies; agglomeration also facilitates the emergence of institutional infrastructure that can ease the functioning of local economy ([5]: 333).

But in most cases culture and leisure clusters are stimulated, encouraged and planned by the public sector and the city's authorities. This is rooted to the fact that clustering of cultural and leisure activities may work as a catalyst to processes of urban redevelopment and renewal in declined and underused inner city areas - mostly former industrial areas. The phenomenon of culture led regeneration of inner city areas has produced new urban forms and landscapes that constitute 'signifying precincts' or epicentres in the post-industrial inner city (see $[22,23])$.

According to Hutton [22], 'signifying precincts' of new urban economies (including culture and leisure) comprise critical production functions, encompass major concentrations of the 'leading edge' or propulsive firms in key new economic sectors and offer special opportunities for social interaction and information exchange. They redefine attributes of consumption, lifestyle and urban imaginary, provide distinctive environmental amenities and contribute to the reformation of local identity. Classification of cultural and leisure epicentres (see [23-25]) according to spatial parameters, such as location in the urban grid, the dominant new economic activities clustered in and the supplementary land uses, the ways space has been produced (development, redevelopment, renewal), and the architectural and urban morphology, present three main types.

High-culture epicentres' are usually located in conserved inner city areas and constituted by clusters of high-culture activities such as museums of various kinds, galleries, theatres, operas, concert halls, convention centres, and the like. Supplementary land uses and activities include bookshops, cafes and trendy restaurants. These epicentres are mostly produced by means of urban renewal and redevelopment. Heritage buildings are redesigned and re-used while also new buildings of innovative urban morphology and architectural design are often added to the area. As typical cases, one may refer to the Museums Quarter in Vienna, The Museums Quarter in Rotterdam, The Museums Quarter in The Hague (see [13, 23-25]).

Popular leisure epicentres' are located in conserved inner city areas and constituted by clusters of leisure activities such as cafes, bars, restaurants, (ethnic and continental), popular-music clubs, etc. Supplementary land uses and activities include antique shops, fashion design shops, music shops, bookshops and avant-garde small theatres. These epicentres are mostly produced by means of urban renewal of conserved urban cores - usually former industrial or residential sites. As typical cases, one may refer to Temple Bar in Dublin, 
Bagladcity in Brick Lane, London, Westergas-fabriek in Amsterdam, Witte de Withstraat in Rotterdam, Psiri in Athens and Ladadika in Thessaloniki, Greece (see [23-25]).

Culture and leisure waterfront epicentres' are mostly located in the heart of inner city, but in some cases also in the urban periphery, and constituted by clusters of culture and leisure activities such as museums of various kinds, convention halls, galleries, concert halls, theatres, parks and promenades. Supplementary land uses and activities include housing, offices, cafes, and restaurants. These epicentres mostly represent development and redevelopment schemes of innovative urban morphology and architectural design - often complemented by renewal schemes of heritage buildings and urban cores. As typical such schemes, recently developed, one may mention South Bank in London, Forum of the Cultures in Barcelona, Abandoibarra in Bilbao, Port Melbourne in Melbourne, West Kowloon in Hong Kong (see [23-25]).

In terms of urban morphology and architectural form, these epicentres usually exhibit a mixture of distinctive avant-garde design schemes combined with conserved and re-used heritage buildings; and in this respect, they generate a new species of 'glocalised' urban landscape [26]. The term 'glocalised' is to mean a new species of urban landscape-collage dominated by two extremities: (a) that of built heritage with rather local spatial references and (b) that of design innovation having more universal or global spatial references [26].

\section{Clusters of culture and leisure in Greek cities: processes of formation, urban landscape transformations and the policies involved}

Since the early 1990s, Greek cities and especially Athens, the capital city, have been experiencing a constant growth of post-industrial new urban economies, ICTs and multimedia, culture and leisure, publishing and mass media, intermediary financial services. Among them, culture and leisure and night-time entertainment appear to be the most developed sectors of new urban economies in Greek cities. More specifically, in respect to the total number of enterprises in all sectors of new urban economies, culture and leisure represents $55 \%$ in Athens and $40 \%$ in Greece as a whole, while night-time entertainment reaches $29 \%$ in Athens and 50\% in Greece as a whole (see [27]).

The growth of cultural and leisure economic activities in Greek cities in the last decade or so, has been accompanied with their clustering in declined inner city areas. As a catalyst, clustering has encouraged urban renewal and redevelopment and has generated whole new quarters and neighborhoods of cultural and leisure activities - shifting the city's spatial structure, transforming urban landscape and creating new epicenters. Most of such cultural and leisure quarters are to be found in metropolitan Greek cities such as Athens and Thessaloniki. But they are also present in middle-sized Greek cities like Patras, Heraklion, Volos, and others. Almost all cultural and leisure quarters have been spontaneously created and informally developed - without spatial planning and financial incentives by local authorities or the state. As a typical cases of 
spontaneous clusters of cultural and leisure activities, we have examined Pireaus Avenue in Athens, the area of Ladadika in Thessaloniki, and the area of Palea in Volos.

\subsection{Pireaus Avenue}

Pireaus Avenue was originally developed in 1835 as the main road connecting Athens to the closely neighbouring harbour city of Pireaus. Due to easy access to both cities and the harbour, most sites along Pireaus Avenue were gradually developed as industrial estates. More than a century later, in the 1970s, due to the decline of traditional industries on the one hand, and the relocation of flourishing industrial plants in properly planned industrial areas in the exurban periphery on the other hand, most of the industrial estates along Pireaus Avenue were abandoned (see [28]). Besides, mass national migration to Attica in the 1950s, 1960s and 1970s had entailed a rapid and dramatic demographic increase of the cities of Athens and Pireaus; and the ensuing urban expansion - mostly based on unplanned and unregulated processes - caused the merge of the two neighbouring cities in Attica. Thus, the industrial character of Pireaus Avenue became incompatible with the surrounding new residential areas. Aiming at resolving this conflict and promoting the redevelopment of this long artery (28.5 $\mathrm{km}$ ), Athens' 1986 master plan enacted laws for the removal of all industries from Pireaus Avenue. As approved land uses were established housing, commercial shops, offices, restaurants, cafes and bars without live music, cultural activities, and car parking. About 170 old industrial building complexes were by law characterised and protected as built heritage. These policies accelerated the removal of all industries from Pireaus Avenue and made this artery an abandoned but protected heritage-axis ready for renewal and redevelopment. Among all approved land uses and activities, culture and leisure started to spontaneously cluster in Pireaus Avenue due to its particular characteristics: (a) easy access to both Athens and Pireaus, (b) large-sized heritage edifices with great potential for redesign and re-use (c) abandoned sites and law real estate prices, and (d) a conserved environment of high cultural value. Thus, in the last decade, Pireaus Avenue has been redeveloping as a cluster of high-culture and popular leisure. A recent land-use survey (see [29]) has shown that very important high-culture institutions - public and private have moved in the area. Among them, the most important are the New Benaki Museum of Modern Arts; Technopolis which is administratively run by the Municipality of Athens and accommodated in the old gas-factory estate $(30,000$ $\mathrm{m}^{2}$ ) and hosting many music and art-events in different halls and auditoriums; Hellinikos Cosmos, a museum and a cultural centre run by the Foundation of Hellenic World, located in an old industrial estate $\left(60,000 \mathrm{~m}^{2}\right)$ and accommodating virtual reality shows and interactive technology-intensive education for pupils and adults, covering subjects such as the ancient Greek history, new technologies, cyberspace and their applications; The School of Fine Arts, University of Athens; Bios Centre, a multimedia art-centre for innovative arts and experimental performances of all kinds hosted in an old factory of 
painting-colours $\left(1,500 \mathrm{~m}^{2}\right)$; the Zigos art gallery and five theatres. In between these high-culture institutions and enterprises are located bars and night-clubs of popular music.

\subsection{Ladadika}

Ladadika is part of the historical centre of Thessaloniki; it represents a well-preserved urban fragment of the $18^{\text {th }}$ and $19^{\text {th }}$ century that escaped destruction from the 1917 great fire which destroyed almost the whole historical centre of Thessaloniki. The area is adjacent to both the city's CBD and the old central harbour pier; it was originally developed as a wholesale trade area, mainly for oil, spices and cereals, and the built fabric consisted of warehouses, workshops and commercial shops. Ladadika was a flourishing trade area until the mid $20^{\text {th }}$ century. Deterioration of the area started in the $1970 \mathrm{~s}$ - mainly in virtue of the increasing competition with supermarkets but also due to the difficult access of Ladadika by car - caused by both the neighbouring of the area to CBD as well as its narrow and tortuous streets. In the 1980s, the decay reached a peak and most of the commercial spaces in Ladadika were underused or non-used. The non-used old buildings were gradually becoming ruins while underused ones were also badly maintained; illegal activities (e.g. drugs smuggling, prostitution, etc.) were taking place in the area. Local authorities and the state - Municipality of Thessaloniki, Ministry of Macedonia and Thrace and especially the local Urban Planning Division of Ministry of Environment, Planning and Public Works - made co-ordinated efforts for the renewal and regeneration of Ladadika (see $[30,31]$ ). The area was by law recognised as heritage urban core; and both public open spaces (including streets, squares, and the like) and 87 old buildings were by law protected as built heritage that ought to be conserved. In the late 1980s and the early 1990s, EU and the Greek state funded through the programme of Urban Pilot Projects, the conservation and renewal of 21 private buildings of high cultural value as well as the renewal of all public open spaces in Ladadika.

However, shortage of public funds favoured the decision to set a strict regulation-framework for the conservation and renewal of the rest private heritage-buildings but leave the financing to private interests - the new tenants of the area. Besides, the fear of failing to attract private funds fast on the one hand, and the ongoing deterioration of private heritage buildings on the other, forced planners and local authorities to abandon their original intention to strictly control land uses in the area and provide incentives for high-culture activities (museums, galleries, etc) and commerce. Thus, popular leisure enterprises (such as cafes, bars, restaurants, music clubs and the like) which were the most affluent enterprises interested to settle in the area, started to invest in the conservation and renewal of heritage buildings and gradually congregate in Ladadika. In a course of a decade or so, Ladadika was spontaneously transformed into a cluster of cultural and leisure activities.

Recent land-use survey (see [32]) has shown that culture and leisure economic activities cover $39.69 \%$ of the total surface of built space in Ladadika. However, the area's development prospects as a cluster of culture and leisure 
appear blurred since there are today a lot of vacant spaces $(10.87 \%)$ in renewed heritage buildings that were earlier occupied. Moreover, between 2003 and 2006, the balance between new cultural and leisure enterprises settled in Ladadika and similar enterprises shutting down in the area is just slightly positive. More specifically, in the above period, 40 new cultural and leisure enterprises appeared while 36 closed.

\subsection{Palea}

Palea is the historical core of the town of Volos. Archaeological excavations in different sites in the area of Palea have identified and partly revealed various levels of archaeological ruins belonging to settlements established one over the other in different historical periods - from prehistory to the Ottoman period. Besides, remnants of the Byzantine and Ottoman walls that have been preserved and conserved now constitute important historical monuments accessible to visitors. Most parts of the walls were demolished, together with the organic street pattern of the Ottoman settlement in Palea, following the 1883 master plan which arranged space so as the new town of Volos in the east and the old fenced settlement in Palea would be integrated into one modern city with a gridiron street pattern. The implementation of the 1883 plan radically changed the morphological and spatial character of Palea. However, due to the neighbouring of the area to both the harbour and the railway station, Palea quickly acquired a new character as an industrial and wholesale area: a large number of small and large industries, workshops, warehouses, wholesale trade and commercial activities developed in the area in the first decades of $20^{\text {th }}$ century (see [33]).

After the catastrophic earthquakes in 1955, the majority of buildings in the town of Volos, including Palea, were largely damaged. The area was reconstructed in the 1960 s as a low-middle class residential area (central part) but lost part of its industrial and commercial activities (northern and southern parts) which were relocated in industrial zone at the outskirts of the Volos. The deterioration of the area continued in the 1970s as a result of (a) the decline of traditional industries, (b) the disconnection of Palea from the fast developing CBD in the central-east part of the city due to the railways boundaries (see Gospodini 1999), (c) the decline of small family workshops and commercial shops in virtue of the increasing competition with large commercial shops in $\mathrm{CBD}$, and (d) restrictions in the reconstruction of sites due to archaeological ruins and their protection. Deterioration processes lasted for more than two decades; and a large number of old industrial buildings, warehouses, workshops and commercial shops were abandoned. The 1992 plan of Volos recognised Palea as a historical urban core requiring renewal and regeneration. Local authorities made efforts to expand CBD towards west and regenerate Palea by moving departments of public services and municipal cultural activities in abandoned old industrial buildings in and around the area of Palea. Among them, the most significant one is the old Tsalapata factory that has been redesigned and re-used as a Museum of industrial heritage.

However, it was neither the state nor local authorities but the dynamic market of night-time entertainment and private funds that steered urban renewal and 
regeneration in Palea. Since the mid 1990s, enterprises such as cafes, bars, music clubs, restaurants and the like, started to gradually settle in the area while conserving and re-using abandoned heritage edifices, thus, impelling the formation and development of a cluster of popular leisure in the central and southern parts of Palea.

Cultural activities, such as multiplex cinemas and shopping centres, art galleries, and a radio-television channel, followed night-time entertainment and created a sub-cluster of culture and leisure in the northern part of Palea. Recent land-use survey (see [34]) has shown that nowadays $27.01 \%$ of the total built up surface is covered by cultural, leisure and creative activities. Among them, culture is most developed in terms of surface covered $(17.07 \%)$ while popular leisure and night-time entertainment are dominant in terms of number of enterprises (44 out of 65).

\section{Conclusions: clusters of culture and leisure in mature and developing European cities: their characteristics and degree of sustainability}

Culture and leisure undoubtedly constitute the growth engine of urban economy in the post-industrial era; and this applies to all classes and groups of cities, from global cities and economically mature large cities in Europe and North America to developing Mediterranean large cities in south and southeast Europe, as well as cities of growth economies in south-east Asia and Australia. However, the formation and developing processes of clusters of cultural and leisure activities seem to create significant differences among groups of cities:

As already described in the introduction, global cities and mature large cities appear to support and control the formation, development, and management of such clusters by means of spatial planning, architectural and urban design and local policies. This is the case in for instance, Vienna's and Rotterdam's Museum quarters; Barcelona's Forum of Civilisations 2004 - a new waterfront complex at the periphery of the city hosting cultural activities from all over the world. Even smaller European cities appear to exhibit successful examples of new cultural and leisure neighbourhoods, comprehensively been planned, designed and managed, such Bilbao's Abandoibarra area along Nervion River and Valencia's City of Arts and Sciences. All of these clusters have also been 'hard-branded' [35] by means of innovative design schemes - products of design competitions or contracts with pioneer architects - enhancing the identity of such epicentres. As such examples may be mentioned the Momuk (Museum Modern Kunst) in Vienna and NAI (Netherlands Architecture Institute) in Rotterdam, Ghery's Guggenheim Museum in Bilbao, or Calatrava's L' Hemispheric in Valencia; innovative design schemes are in some cases added to existing heritage built fabric, thus, generating a kind of 'glocal' urban landscape in the cluster (see [26]).

In contrast to the above, the Greek experience shows that epicentres of high-culture and leisure, like that of Pireaus Avenue in Athens, are characterised 
by spontaneous formation and 'laissez-faire' development and management. Interviews with directors of high-culture enterprises (e.g. museums, art galleries and the like) as well as the managerial personnel of night-time entertainment enterprises located in the area of Pireaus Avenue, have shown a low interest of local authorities and the state in both the formation and development processes of the cluster. Interviewees remonstrated about the following: First, renewal or/and redevelopment processes in heritage industrial estates - both public and private - exhibit a slow pace since no economic incentives have been established by local authorities or the state. Second, there are public open spaces on Pireaus Avenue that have not yet been renewed whereas those redesigned and reconstructed are not decently maintained but they often constitute 'no go spaces' [18]. Third, public transportation along Pireaus Avenue is not satisfactory. Fourth, there is still a law banishing the function of clubs and restaurants with live music on Pireaus Avenue, although such enterprises have been flourishing in the area almost a decade now and are still illegally operating without a proper licence. Fifth, interviewees expressed their wish for a possible co-operation in the cluster in order to host mega cultural events, distributed all over the various building complexes.

In the case of popular leisure clusters, differences are also significant between mature cities and Mediterranean large cities. Mature cities appear to imply incentives encouraging the formation and development of such clusters. As Hitters and Richards [17] argue through the analysis of Witte de Withstraat in Rotterdam and Westrgasfabriek in Amsterdam, the particular management approach adopted by local authorities to the renewal and transformation processes of such conserved urban cores into popular leisure epicentres may have critical results in the variety of functions and activities clustered, the cluster's degree of creativity as incubation space, the image of the area and place identity. However, the Greek experience shows also in this case a spontaneous formation and a kind of a 'laissez-faire' development. For instance, the lack of land-use control by local authorities in the case of Ladadika, as earlier described, has finally entailed the cluster's mono-functional identity - i.e., activities almost exclusively confined to cafes, bars, restaurants - and thereby, a low degree of creativity and perhaps a low degree of sustainability. As a first sign of decay in the area, one may note that during the last years, the number of enterprises opening and the number of those closing in Ladadika are almost equal. Interviews (see $[32,34]$ ) with managerial personnel of night-time entertainment enterprises located in the areas of Ladadika and Palea has revealed the lack of strong efforts and special policies by local authorities. Interviewees complained about the lack of financial incentives for attracting high-culture institutions and activities, the conditions of maintenance of public open spaces, and the delay of renewal processes in the very few heritage buildings that have not yet renewed ( $0.69 \%$ of the total built surface).

All the above highlight the inefficiency of local authorities in some Mediterranean cities in south-east Europe (a) to invest in planning and design of new cultural and leisure epicentres and (b) to produce local policies for their formation, development and management (see [36,37]). Possible shortage of 
finance may not always explain the established 'laissez-faire' practices; it seems that there is also a lack of understanding about the characteristics of the post-industrial era, the profile of the growing post-modern societies, the growth potential of cultural and leisure economies and the critical importance of the new epicentres in the development prospects of cities in the new era. However, in the framework of the increasing intercity competition and the fast growing new urban economies, Mediterranean cities like Greek cities have to launch new strategies following what Mommas [13] has called a shift towards creating quarters and milieus for cultural production and creativity".

\section{References}

[1] Bianchini, F. (1993), 'Culture, conflict and cities: issues and prospects for the '90s' in Bianchini, F. and Parkinson, M. (eds.), Cultural policy and urban regeneration: the West European experience, Manchester: Manchester University Press.

[2] Zukin, S. (1995) The Cultures of Cities Cambridge Mass: Blackwell Publishers ltd.

[3] Lash, S., Urry, J. (1994), Economies of signs and space. New York: Sage.

[4] Castells, M. (1996), The rise of the Network Society, MA: Oxford and Malden.

[5] Scott, A. J. (1997) 'The Cultural Economy of Cities', International Journal of Urban and Regional Research 21(2): 323-339

[6] Scott, A. (2000), The cultural economy of cities. London: Sage.

[7] Hall, P. (2000), 'Creative Cities and Economic Development', Urban Studies 37(4): 639-649.

[8] Crompton, J. L., Mackay, S. L. (1994), 'Measuring the economic impact of festivals and events; some myths, misapplications and ethical dilemmas', Festival Management and Event Tourism 2(1): 33-34.

[9] Pratt, A. C. (1997) 'The cultural industries sector: its definition and character from secondary sources on employment and trade - Britain 1984-91', Research Papers on Environmental and Spatial Analysis, No.41, London School of Economics.

[10] Hobbs, D., Lister, S., Hadfield, Ph. (2000), 'Receiving shadows: governance and liminality in the night-time economy', British Journal of Sociology 51(4): 701-717.

[11] Hollands, R., and Chatterton, P. (2003), 'Producing Nightlife in the New Urban Entertainment Economy: Corporatization, Brading and Market Segmentation', International Journal of Urban and Regional Research 27(2): 361-385.

[12] Clark T. N., Lloyd R., Wong, K. K., Jain, P. (2002) Amenities Drive Urban Growth, Journal of Urban Affairs: 24(5):493-515.

[13] Mommaas, H. (2004), 'Cultural Clusters and the Post-industrial City: Towards the Remapping of Urban Cultural Policy', Urban Studies 41(3): 507-532. 
[14] Krätke, S. (2002), 'Network Analysis of Production Clusters: The Potsdam/Babelsberg Film Industry as an Example', European Planning Studies 10(1): 27-54.

[15] Bassett, K., Griffiths, R., Smith, I. (2002), 'Cultural industries, cultural clusters and the city: the example of natural history film-making in Bristol', Geoforum 33: 165-177.

[16] Turok, I. (2003), 'Cities, Clusters and Creative Industries: The Case of Film and Television in Scotland', European Planning Studies 11(5): 549565 .

[17] Hitters, E. Richards, G. (2002), 'The Creation and management of Cultural Clusters', Creativity and Innovation management 11(4): 234-247.

[18] Roberts, M. (2006), 'From 'creative city' to 'no-go areas' - The expansion of night-time economy in British town and city centres', Cities 23(5): 331-338.

[19] Crewe, L. (1996), 'Material Culture: embedded firms, organizational networks and the local economic development of a fashion quarter', Regional Studies 30(3): 257-272.

[20] Creigh-Tyte, A. (2005), 'Measuring Creativity: A case study in the UK's Designer Fashion sector', Cultural Trens 14(2): 157-183.

[21] Shaw, S, Bagwell, S., Karmowska, J. (2004), 'Ethnoscapes as Spectacle: Reimaging Multicultural Districts as New Destinations for Leisure and Tourism Consumption', Urban Studies, 41(10): 1983-2000.

[22] Hutton, Th.A. (2004), 'The new Economy of the Inner City', Cities, 21(2): 89-108.

[23] Gospodini, A. (2006), 'Portraying, Classifying and Understanding the emerging new Landscapes in the Post-industrial city', Cities 23(5): 311331.

[24] Gospodini, A. (2005), 'Landscape Transformations in the Postmodern Inner City: Clustering flourishing economic activities and 'glocalising' morphologies', Proceedings of the international conference Sustainable Planning and Development, Bologna 12-14 Sept. 2005: 1469-1485.

[25] Gospodini, A. Beriatos, E. (2006), (eds), New Urban Landscapes and the Greek City, Athens: Kritiki Publications (in Greek).

[26] Beriatos E., Gospodini, A. (2004), "Glocalizing Urban Landscapes Athens and the 2004 Olympics", Cities 21(3): 187-202.

[27] Gospodini, A. (2007), 'Post-industrial trajectories of Mediterranean European cities. Learning from post-Olympics Athens and the Greek experience', in Th. A. Hutton (ed) Trajectories of the New Economy: An International Investigation of Inner City Regeneration and Dislocation', Urban Studies, theme issue (forthcoming).

[28] Sariyannis, G. (2000), Athens 1830-2000: Urban development, Planning and Transports, Athens: Symmetry Editions (written in Greek).

[29] Papadema, P. (2006a), Pireaus Avenue, Athens: Investigating the formation and management of the cluster of new economies, student research project supervised by Dr. Aspa Gospodini, Associate Professor, 
MSc course 'Urban Planning and Development', Department of Planning and Regional Development, University of Thessaly, Volos, Greece.

[30] Voulgaris, A. (1998), Prospects and Potentials of Applying Programmes of Urban Renewal in the contemporary Greek city' (in Greek), also translated in Italian as "Prospettive e possibilita di applicazione dei programme di recupero urbano nella citta grace contemporanea', in Infussi, F., and Simioforides, Y., (eds.), Programma Heracles, Le sfide della citta greca, Athens: Linora, pp. 170-179.

[31] Mavromatis, M. (1995), Ladadika: From abandonment to conservation and regeneration, report, Direction of Environment and Planning, Division of Central Macedonia, Ministry of Environment, Planning and Public Works.

[32] Koukoulis, G. (2006), The Cultural and Leisure Cluster in Ladadika, Thessaloniki: Investigating the spatial and economic parameters, Diploma Thesis, supervised by Dr. Aspa Gospodini, Associate Professor, Department of Planning and Regional Development, University of Thessaly, Volos, Greece.

[33] Hastaoglou, V. (2002), Volos: The portrait of the city in the $19^{\text {th }}$ and $20^{\text {th }}$ centuries, Volos: Municipality of Volos Publications (in Greek).

[34] Papadema, P. (2006b), Palea, Volos: The transformation of the area into a cluster of cultural and leisure activities, MSc Thesis, supervised by Dr. Aspa Gospodini, Associate Professor, MSc course 'Urban Planning and Development', Department of Planning and Regional Development, University of Thessaly, Volos, Greece.

[35] Evans G. (2003), 'Hard-Branding the Cultural City - From Prado to Prada', Journal of Urban and Regional Research 27(2): 417-440.

[36] Leontidou, L. (1993), 'PostModernism and the City: Mediterranean versions', Urban Studies 30(6): 949-965.

[37] Leontidou, L. (2006), 'Multi-culture and Heterotopia in the Mediterranean Urban Landscape: from spontaneous urbanisation to the entrepreneurial city', in A. Gospodini and E. Beriatos (eds), New Urban Landscapes and the Greek City, Athens: Kritiki Publications: 70-84 (in Greek). 